\title{
COVID-19 monetary transfer in El Salvador: determining factors
}

\section{Carlos Ayala Durán 1}

1 Universidade Federal do Rio Grande do Sul, Porto Alegre / RS - Brazil

\begin{abstract}
Given the lack of governmental guidelines, this paper identifies and analyzes the statistical determinants associated with receiving the onetime monetary transfer in El Salvador ( $\$ 300$ dollars) as an economic measure to face the COVID-19 pandemic. A logistic regression was implemented (whether received the transfer or not) based on a probabilistic sample $(n=1222)$ of surveyed people throughout the country. Independent variables were selected drawing upon key characteristics employed internationally in monetary transfers: age, gender, rural area, employment, family income, and education. The text identifies a statistically significant and negative relation between receiving the monetary transfer and two variables: family income and educational level. The need to increase coverage of the program is addressed as well as the importance of considering age, gender, rural areas, and employment as criteria for selecting the beneficiaries in such economic measures.
\end{abstract}

Keywords: COVID-19; Central America; economic policy; economic reactivation.

\section{Transferência de renda em El Salvador diante da COVID-19: fatores determinantes}

Dada a ausência de diretrizes governamentais, o texto apresenta uma análise exploratória e identifica quais são os fatores estatísticos determinantes que explicam a transferência única de renda ( $\$ 300$ dólares) como medida econômica para enfrentar a pandemia gerada pela COVID-19 em El Salvador. Para tal fim, utiliza-se uma análise estatística de regressão logística (receber ou não a ajuda) com base em uma amostra probabilística de respondentes em todo o país $(n=1222)$. Como variáveis independentes emprega-se caraterísticas importantes utilizadas em programas de transferência de renda em todo o mundo: Idade, gênero, zona de procedência, emprego e renda familiar e nível educacional. O presente texto identifica que existe uma relação inversa e estatisticamente significativa entre essa ajuda pública com a renda familiar e o nível educacional. Finalmente, discute-se a necessidade de ampliação do programa econômico e a importância de considerar características como idade, gênero, zona de procedência e emprego nesse tipo de políticas econômicas.

Palavras-chave: COVID-19; América Central; política econômica; reativação econômica.

\section{Transferencia monetaria en El Salvador ante la COVID-19: factores determinantes}

Ante la falta de lineamientos gubernamentales, el presente texto muestra un análisis exploratorio e identifica cuáles han sido los determinantes estadísticos asociados a la recepción de la transferencia monetaria única ( $\$ 300$ dólares) como medida económica para enfrentar la pandemia de COVID-19 en El Salvador. Para tal efecto, se utiliza un análisis estadístico de regresión logística (recibir la ayuda o no) con base en una muestra probabilística de encuestados en todo el país $(n=1222)$. Como variables independientes se emplean características cruciales utilizadas en programas de transferencias monetarias a nivel internacional: Edad, género, lugar de origen, empleo, ingresos familiares y nivel educacional. El presente texto identifica que existe una relación inversa y estadísticamente significativa entre la asignación de esa ayuda pública, los ingresos familiares y el nivel educacional. Finalmente, se discute la necesidad de ampliación del programa y la importancia de considerar aspectos como edad, género, lugar de origen y empleo en ese tipo de políticas económicas.

Palabras clave: COVID-19; Centroamérica; política económica; reactivación económica. 


\section{ACKNOWLEDGEMENTS}

The author would like to express his gratitude to the Center for Citizen Studies (Centro de Estudios Ciudadanos) from the Francisco Gavidia University for facilitating the database. The pandemic and lockdown order did not stop them from doing a tremendous work. Additionally, it is worth mentioning the invaluable and crucial collaboration provided by Sofia Grimaldi. Her kind words and support validating the model is greatly appreciated. Any remaining errors are the author's responsibility.

\section{INTRODUCTION}

The Coronavirus (COVID-19) pandemic has posed new challenges for countries worldwide, including those in Latin America. In response to the pandemic, countries have come up with different measures at sanitary, social, and economic levels. Within this context, the Government of El Salvador earlier implemented policies to tackle the pandemic's adverse effects. Since March 2020, a battery of aggressive initiatives to face the pandemic's consequences was implemented, including suspension of onsite classes, the prohibition of certain jobs, closure of airports, strict quarantine, lockout orders, and economical transfers.

The following text focuses on one of the most notorious and costly actions: The onetime $\$ 300$ monetary transfer. The present text looks to perform exploratory analysis and to identify the statistical determinants that explain the concession of that transfer. To that effect, a logistic regression was implemented allowing to estimate and analyze the determining factors associated with receiving the public benefit. Drawing upon international literature, this regression took as independent variables worldwide known determining characteristics on public monetary transfers, namely: age, gender, employment, rural/urban area, income, and education.

Three main grounds justify this work: the need to come up with efficient economic responses to face COVID-19 in El Salvador, the additional budgetary pressure the transfer poses upon public spending (\$450 million), and the absence of clear governmental guidelines to select recipients. To that effect, after the introduction, a brief contextualization of El Salvador fighting the pandemic is elaborated. Later on, materials and methods are addressed. This paves the way to present results and its pertinent discussion. Lastly, final remarks are elaborated.

\section{THE PANDEMIC IN EL SALVADOR AND ITS SOCIAL CONTEXT: A SNAPSHOT}

El Salvador was one of the Latin American countries that most rapidly took serious measures to prevent the spreading of COVID-19. Whether focusing on the health, economic, or social initiatives, there is a consensus of how pertinent it was to implement drastic measures when the country only registered three positive cases of COVID-19. All these actions made it possible to initially slow down the spreading of the virus. Despite the original celerity, many of these measures have been surrounded by controversies, given the lack of technical guidelines, improvisation or disregard for human rights and democratic ruling. Hence, numerous national organizations have highlighted extreme arbitrariness and illegal actions carried out by the Salvadorian Government, particularly during the country's lockdown order (Gavarrete, 2020a; Vaquerano, 2020). 
Moreover, both public and private international organizations have joined local actors by sharing their unease about measures the Salvadorian Government implemented since the beginning of the pandemic. Some of those international voices include renowned institutions such as Human Rights Watch (González, 2020), The United States Congress (Engel \& Sires, 2020; Mcgovern, 2020), the Central American Institute for Fiscal Studies (Orellana, 2020b), The Economist (2020) or The Washington Post (Valencia, 2020).

A recent editorial note of The Economist (2020) warned about the risk of Salvadorian president Nayib Bukele to become the first millennial dictator, summing up multiple shortcomings and concerns surrounding the pandemic's response. Despite the area of expertise and origin from these organizations, there is a common point of criticism: The absence of clear guidelines or technical parameters to lead the way when facing the pandemic's effect. This lack of guidelines appears to be shared across health, logistic, social and economic measures.

Focusing on economic actions to cope with the pandemic's fallout, and similarly to what other countries around the world have done (Gentilini, Mohamed \& Almenfi, 2020), the Salvadorian Government implemented a battery of measures including the restriction of certain jobs, the prohibition of firing workers, payment suspension for basic services, and a onetime $\$ 300$ monetary transfer to 1.5 million households. According to the Salvadorian President, this cash transfer would reach $75 \%$ of households nationwide, at an estimated cost of $\$ 450$ million (Lemus, 2020).

Given that a strict lockdown order was implemented, this monetary transfer promised latent positive effects. However, the initiative faced major challenges since its designing phase. Two of the most pressing ones were the fiscal burden and limited resources available. Thereof, El Salvador reported that by 2019 the debt-to-GDP ratio exceeded 70\%, and the fiscal deficit reached 3\% (Orellana, 2020a).

Additionally, this public program lacked clear selection, control, and accountability mechanisms, a common trait of other governmental initiatives. It is then worth nothing that even the Republic's Auditing Court has not able to determine how numerous recipients of the cash transfer program were selected (Campos, 2020). The only source of official information available was verbal statements and interviews from high-level government officials expressing the transfer program targeted families with lower income as established by the public register for subsidies (propane gas and electricity). Assuming this cash transfer effectively relies on the public subsidy register, a significant challenge regarding coverage arises.

According to official data, $12.7 \%$ of El Salvador households do not possess electricity, while $8.9 \%$ do not use gas for food preparation (Dirección General de Estadísticas y Censos [DIGESTYC], 2019). Those figures are substantially higher for Salvadorian rural areas. Hence, an undetermined number of up to 409.444 households could be potentially excluded from the money transfer program, as they do not receive other public subsidies. It comes then as no surprise, newspapers reported a number of low-income families excluded from the cash transfer initiative (Gavarrete, 2020a, 2020b; Guzmán, 2020; Vaquerano, 2020).

Besides the coverage problem, all evidence indicates that this cash transfer program was not designed to support vulnerable groups, which are usually subject to similar international policies. These prioritizing groups include women (World Bank Gender and Development Group, 2003), elders, or rural households (Molyneux, 2006). 
Moreover, registering as the recipient and the installment reception was not exempt from controversy. The transfer program was commanded by the National Center for Subsidy Management (CENADE), an institution dependent on the Ministry of Economics. Different CENADES are located throughout the country, existing one office per department, except for the capital San Salvador that is home to three agencies. This distribution mechanism proved inefficient, causing chaos and massive agglomerations even when a strict lockdown order was in place. Various reports pointed this inadequacy due to the low number of CENADE offices, the 1.5 million potential recipients, deficient subscribing mechanisms, and poor payment scheduling (Guzmán, 2020).

Before the many uncertainties surrounding the money transfer program, there is an increasing need to establish and estimate the determining factors associated with receiving the public benefit. To that end, the specialized literature on monetary transfer provides solid grounds to be considered in El Salvador. Hence, international studies report that people with low income are usually subject to this kind of policy. Within low income households, other priority groups include minors (Handa, 2009), homeless and handicapped (Schuering, 2009). Social fragility conditions such as poor health and education access are also considered selecting criteria in such public programs (Barber \& Gertler, 2009; Bradshaw, 2008). Some other times, granting this type of cash transfer to women is desired, given an additional multiplying effect reported to female transfer initiatives (World Bank Gender \& Development Group, 2003, p. 5).

Despite all this literature, the Salvadorian COVID-19's money transfer program did not elaborate explicit technical parameters for recipient selection. Instead, the only official information came from senior official's verbal statements pointing that recipients of the transfer would be those households already receiving other public subsidies. Within this opaque atmosphere and before the lack of public information, the following text looks to draw up statistical determinants associated with becoming a participant to the program. The present study focusing on El Salvador considers determining characteristics identified by specialized literature on international monetary transfers. Hence, this text was elaborated according to the following materials and methods.

\section{MATERIALS AND METHODS}

There is no official data or public database pertaining to recipients of this money transfer in El Salvador. Therefore, for this paper, the private database provided by the Centro de Estudios Ciudadanos (2020) from the Francisco Gavidia University was used. This organization conducted a bigger study surveying adults (18 years or older) throughout the country, using a probabilistic random sample reaching 1222 respondents. The sample relied on a $95 \%$ confidence interval and a $2.5 \%$ sampling error. The survey was conducted by phone call, using either landline or cellphone, and the information was gathered between April $23^{\text {rd }}-27^{\text {th }}, 2020$.

For the statistical analysis, a logistic regression was employed. Being the recipient of the $\$ 300$ money transfer (yes=1) was used as a dependent variable. As table 1 shows, age, gender, employment, area, education, and income were used as independent variables. These last two variables are categorical, stratified by different income and education levels. For these specific variables, the first value was the base of comparison. Hence, having no formal education (value $=0$ ) and income below $\$ 211$ (value $=1$ ) were their respective base category. 
TABLE 1

VARIABLES USED IN THE LOGISTIC REGRESSION

\begin{tabular}{|c|c|c|}
\hline Variable & Scale & Description \\
\hline Age & continuous & Age of respondent in years. \\
\hline Gender & $0-1$ & Value 0 corresponds to men and 1 to women. \\
\hline $\begin{array}{l}\text { Employ } \\
\text { ment }\end{array}$ & $0-1$ & Value 0 corresponds to unemployed people and 1 to employed. \\
\hline Area & $0-1$ & Value 0 corresponds to people living in urban areas and 1 for people in rural areas. \\
\hline Education & $0-6$ & $\begin{array}{l}\text { Corresponds to the last level of completed education. Respondents were able to choose } \\
\text { from the following levels of education: } \\
0=\text { no formal education } \\
1=\text { elementary studies }\left(1^{\circ}-6^{\circ} \text { years }\right) \\
2=\text { middle studies }\left(7^{\circ}-9^{\circ} \text { years) }\right. \\
3=\text { high school } \\
4=\text { technical studies } \\
5=\text { university degree } \\
6=\text { postgraduate }\end{array}$ \\
\hline Income & $1-6$ & 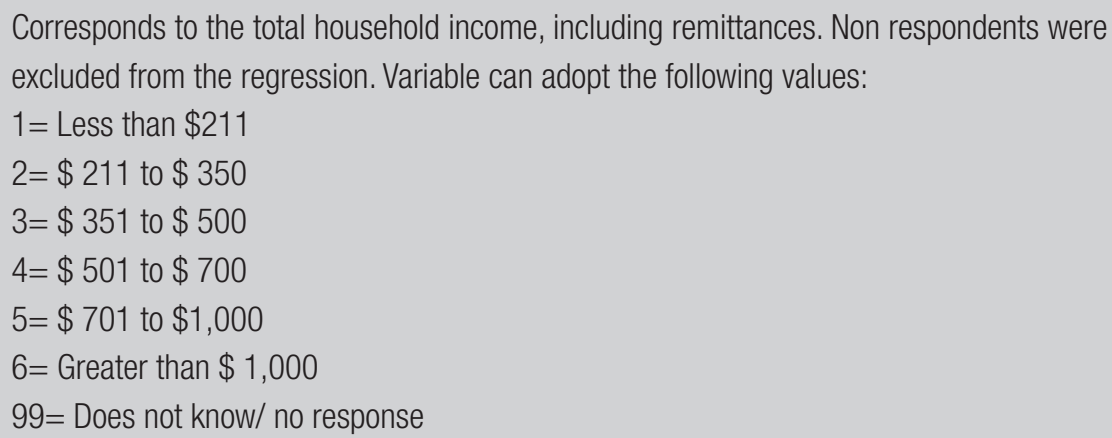 \\
\hline
\end{tabular}

Source: Elaborated by the author.

Three parameters were used to evaluate the logistic regression model's pertinence: Classification tables, Hosmer \& Lemeshow test, and ROC curve. The regression showed a classification table value of 76.8 (block 1, enter) while block 0 reported only 74.5. Hosmer and Lemeshow test had a statistical significance of 0.511 . Meanwhile, ROC analysis showed an area under the curve of 0.727 and a significance level of 0.000 . Thereof, all three parameters show adequate results, providing statistical evidence supporting model fit.

\section{LIMITATIONS}

Despite having many respondents $(\mathrm{n}=1222)$ and using a probabilistic sample, the survey was conducted only via phone call. Hence, people not having an active phone line would be automatically excluded. Similarly, there might be limitations when using phone surveys compared to personal surveys (Holbrook, Green \& Krosnick, 2003). Nonetheless, given the mobility restrictions imposed by the lockdown order at the time, it was virtually impossible to apply the instrument face to face. 
Additionally, since there are no public parameters for selecting recipients, it was not possible to include those characteristics as independent variables. Thereof, this paper aims to identify underlying factors that resulted determinant to become a recipient, based on relevant aspects brought to light by specialized literature on money transfers worldwide.

\section{RESULTS}

From the total respondents ( $\mathrm{n}=1222)$, a total of 310 received the monetary transfer. Their distribution, according to income, is represented by figure 1 . In general terms, there is a negative association between income and the number of recipients, which accounts for an expected tendency.

\section{FIGURE $1 \quad$ DISTRIBUTION OF RECIPIENTS ACCORDING TO INCOME LEVEL}

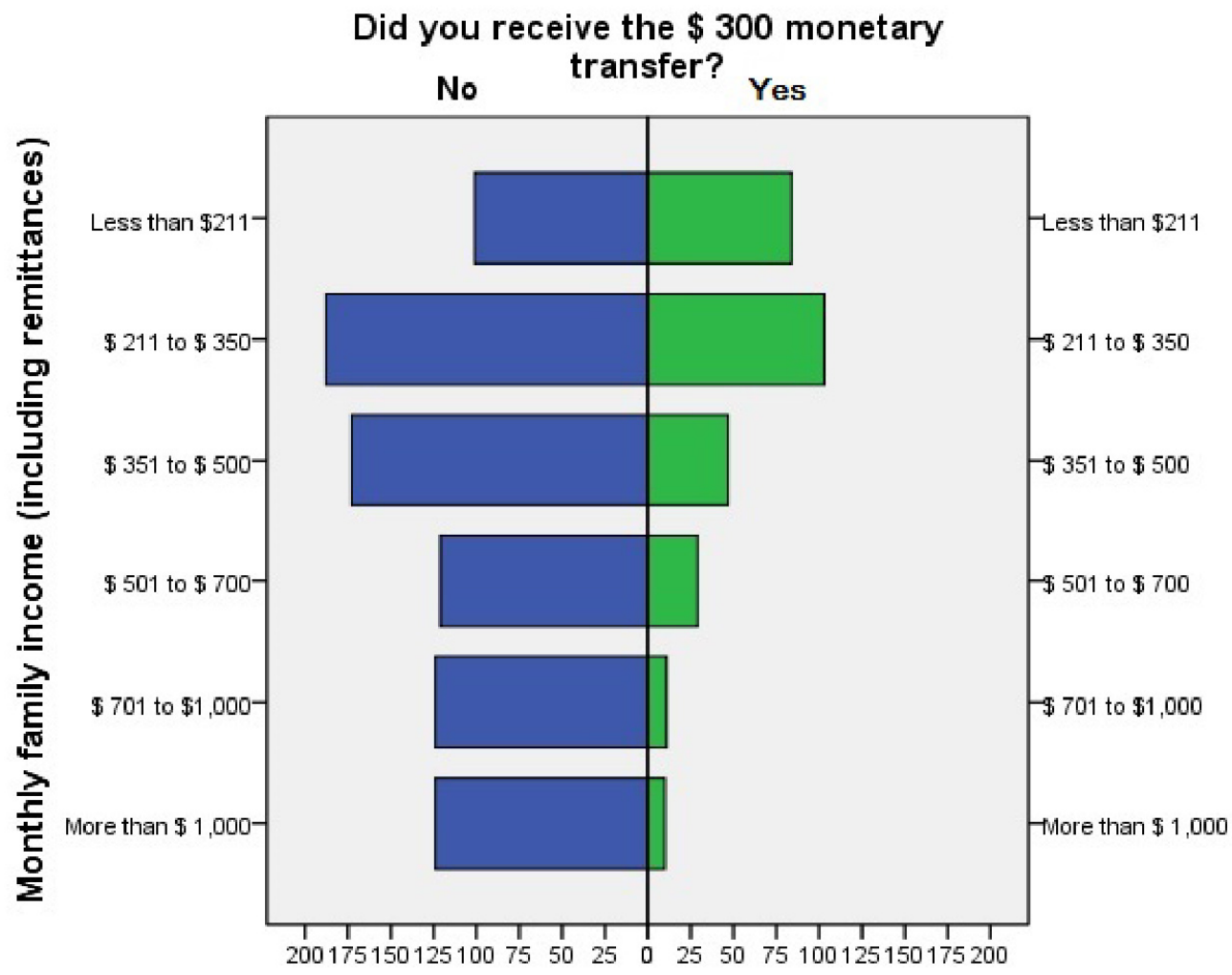

Source: Elaborated by the author based on Centro de Estudios Ciudadanos (2020).

On the other hand, the result of the regressions is presented in table 2. Surprisingly, age, employment, area, and gender did not report statistically significant values. It is particularly worth noting that unemployment, especially under emergency circumstances, is a crucial reason for implementing monetary transfer programs. 


\section{TABLE 2 RESULT OF THE LOGISTIC REGRESSION}

\begin{tabular}{|c|c|c|c|c|c|c|c|c|c|}
\hline \multicolumn{10}{|c|}{ Variables in the Equation } \\
\hline & & \multirow[b]{2}{*}{ B } & \multirow[b]{2}{*}{ S.E. } & \multirow[b]{2}{*}{ Wald } & \multirow[b]{2}{*}{ df } & \multirow[b]{2}{*}{ Sig. } & \multirow[b]{2}{*}{$\operatorname{Exp}(B)$} & \multicolumn{2}{|c|}{$\begin{array}{c}95 \% \text { C.I.for } \\
\text { EXP(B) }\end{array}$} \\
\hline & & & & & & & & Lower & Upper \\
\hline \multirow{18}{*}{ Step $1^{\text {a }}$} & Age & .005 & .005 & .834 & 1 & .361 & 1.005 & .995 & 1.015 \\
\hline & Women (0= Men) & 174 & .153 & 1.304 & 1 & .253 & 1.190 & .883 & 1.606 \\
\hline & Employed ( $0=$ Unemployed) & -.235 & .163 & 2.064 & 1 & .151 & .791 & .574 & 1.089 \\
\hline & Rural Area (0= Urban) & .213 & 179 & 1.410 & 1 & .235 & 1.237 & 871 & 1.756 \\
\hline & Schooling: None & & & 20.511 & 6 & .002 & & & \\
\hline & Elementary $\left(1^{\circ}-6^{\circ}\right.$ years $)$ & -.950 & .560 & 2.873 & 1 & .090 & .387 & .129 & 1.160 \\
\hline & Middle S. ( $7^{\circ}-9^{\circ}$ years) & -1.276 & .568 & 5.048 & 1 & .025 & .279 & .092 & .850 \\
\hline & High school & -1.564 & .558 & 7.861 & 1 & .005 & .209 & .070 & .625 \\
\hline & Technical studies & -2.268 & .654 & 12.015 & 1 & .001 & .104 & .029 & .373 \\
\hline & University degree & -2.003 & .588 & 11.614 & 1 & .001 & .135 & .043 & .427 \\
\hline & Postgraduate degree & -20.768 & 9375.508 & .000 & 1 & .998 & .000 & .000 & . \\
\hline & Income: Less than $\$ 211$ & & & 26.277 & 5 & .000 & & & \\
\hline & $\$ 211-\$ 350$ & -.098 & .210 & .217 & 1 & .641 & .907 & .602 & 1.368 \\
\hline & $\$ 351-\$ 500$ & -.588 & .246 & 5.707 & 1 & .017 & .555 & .343 & .900 \\
\hline & $\$ 501-\$ 700$ & -.531 & .289 & 3.384 & 1 & .066 & .588 & .334 & 1.035 \\
\hline & $\$ 701-\$ 1000$ & -1.454 & .378 & 14.765 & 1 & .000 & .234 & .111 & .490 \\
\hline & More than $\$ 1000$ & -1.394 & .400 & 12.171 & 1 & .000 & .248 & .113 & .543 \\
\hline & Constant & .705 & .637 & 1.224 & 1 & .269 & 2.023 & & \\
\hline
\end{tabular}

a. Variable(s) entered on step 1: Age, Gender, Employment, Area, Education, Income.

Source: Elaborated by the author.

Furthermore, statistical evidence points to an existing negative relationship between education level and the odds of receiving the governmental transfer. This pattern shows a clear tendency from the substrata of people who completed middle studies up until university studies.

Additionally, results show a negative relationship between family income and the odds of receiving governmental transfer. People possessing family income from the strata $\$ 351-\$ 500$ until more than $\$ 1000$ are less prone to receive the money transfer. According to these results, the higher-income people are less likely to receive the public transfer. 


\section{DISCUSSION}

Firstly, it is worth highlighting that only $25.4 \%$ of surveyed people received the governmental monetary transfer. This represents a low coverage level of the public initiative, particularly when considering two key elements of its designing: i) it was supposed to benefit $75 \%$ of households (Lemus, 2020) and ii) poverty levels amounted to $26.3 \%$ in 2018 (Digestyc, 2019). Focusing on the low coverage level, press articles published by Gavarrete (2020b) or Guzmán (2020) already reported excluding impoverished households from the transfer. On the other hand, it is expected for poverty levels to increase since the second quarter of 2020, with imminent consequences in other human development indicators as food and nutritional security index (Ayala, 2020).

Moreover, four independent variables did not show significant statistical values: Age, area, gender, and employment. Specifically, focusing on gender, numerous cash transfer programs the international level have witnessed positive effects targeting female recipients (Barber \& Gertler, 2009; Bradshaw, 2008; Paxson \& Schady, 2007). Similarly, other studies stress the existence of additional positive effects linked to female transfer compared to male transfers (World Bank Gender \& Development Group, 2003, p. 15). Despite all this evidence, results for El Salvador point out that gender was not taken into consideration when creating the money transfer program. Given results and practice in other international contexts, gender could be an essential characteristic when designing money transfer initiatives in El Salvador.

Furthermore, living in a rural area did not present statistically significant values. Considering that poverty levels are substantially higher in Salvadorian rural areas (Digestyc, 2019) and that several monetary transfer programs focus on these spaces (Molyneux, 2006), rural territories should be subject of special attention by Salvadorian public policies.

Surprisingly, a variable that did not report significant values for receiving the cash transfer was being unemployed. In the context of the COVID-19 pandemic, one of the most cited arguments when designing these types of cash transfers in El Salvador and around the world is the vulnerability caused by unemployment. Losing jobs can drag families into poverty, especially in countries like El Salvador, which lack other social protection benefits such as unemployment insurance. Therefore, it was expected that unemployed people would be more prone to receive the monetary transfer; however, results show otherwise.

Closely related to unemployment, income did prove to be determinant to receive the cash transfer from a statistical point of view. Hence, an inverse relationship between receiving the cash transfer and three categories of income were identified for the following strata: $\$ 351-\$ 500(\mathrm{OR}=0.555, \mathrm{p}<0.017)$, $\$ 701-\$ 1000(\mathrm{OR}=0.234, \mathrm{p}<0.000)$ and more than $\$ 1000(\mathrm{OR}=0.248, \mathrm{p}<0.000$. If these income categories were compared vis a vis with those who reported a family income of less than $\$ 211$ (base category), the group with lower income would report greater odds of receiving the money transfer. This seems to be by far the greatest achievement of the money transfer program. Such a finding can be partially explained by the fact that the Government took as main selection criteria households already receiving other public subsidies (propane gas and electricity). Hence, if the designing of the money transfer program did effectively relied on the recipient's list of other public subsidies, it is only natural that lower-income families would have greater odds of receiving this onetime benefit amid the COVID-19 crisis. However, exclusively relying on the public register for electricity and gas subsidies 
poses additional challenges to other complementary economic policies to face the pandemic. As mentioned above, $12.7 \%$ of households do not have electricity, accounting for $21.9 \%$ in rural areas (Digestyc, 2019). Similar tendencies are identified for gas usage, given that $8.9 \%$ of households do not employ it, reaching $19.6 \%$ in rural areas (Digestyc, 2019). Thereof, a collective of families with particularly fragile conditions, ranging from 166.395 - 409.444, would be potentially excluded from the COVID-19 monetary transfer. Hence, using holistic selection criteria and improving allocation mechanisms would prove convenient to increase coverage. To this end, updating the Unified Recipient Register (Registro Único de Beneficiarios), as elaborated by the now extinct Presidential's Technical Secretary, would be a proper way forward (Gavarrete, 2020a).

Finally, education showed a negative and significant $(\mathrm{p}<0.05)$ tendency compared to receiving the monetary transfer. Thereof, middle, high, technical, and university studies presented statistically significant values compared to base category (no formal studies). For example, having a university degree reports fewer odds ratio of becoming a recipient $(\mathrm{OR}=0.135, \mathrm{p}<0.001)$. If the general assumption that higher educational levels associate with a positive effect on income, the reported result for El Salvador is expected. Nonetheless, education was not an element explicitly taken into consideration when designing the public monetary transfer.

\section{FINAL REMARKS}

As noted by results and based on the sample, the onetime $\$ 300$ public monetary transfer shows low coverage levels in El Salvador. Challenged by more than $25 \%$ of poverty levels, and with an economic shrinkage perspective due to the COVID-19 pandemic, it becomes increasingly necessary for Salvadorian authorities to expand the coverage of this type of initiative as well as designing additional policies. However, increasing monetary transfer coverage would necessarily require at least two additional factors: i) in-depth knowledge of the total recipients and ii) usage of clear and perhaps additional selecting mechanisms. The former has not yet been informed by the Government until this date, while the latter would imply significant additional logistic and administrative efforts.

Likewise, it is increasingly crucial to formulate technical parameters for recipient selection. Such parameters should be available for public scrutiny, allowing policy accountability and evaluation. The existence of such guidelines would also allow to explicitly focus on assisting the most vulnerable households. Thereof, recipients of other subsidies can be a good starting group for program inclusion; however, it is compelling to consider possibly excluded households, particularly those facing fragile socio-economic conditions. The efficient use of economic resources becomes an unavoidable responsibility for the Salvadorian Government, given a decreasing availability of resources and a deteriorating fiscal perspective for 2020 and 2021.

Lastly, as the present text highlights, only income and education have proven to be statistically significant variables associated with receiving the money transfer. As international literature on this type of policy depicts, characteristics as employment, age, rural areas, and gender arise as potential elements to consider when designing monetary transfer initiatives and other economic countermeasures for El Salvador. The inclusion of these additional elements would prove crucial for the country, as complementary economic initiatives to tackle the pandemic's effect are being designed and further policies are yet to be announced. 


\section{REFERENCES}

Ayala Durán, C. (2020). Seguridad Alimentaria y Nutricional en tiempos de COVID-19: Perspectivas para El Salvador. Revista Latinoamericana de Investigación Social, 3(1), 42-46.

Barber, S., \& Gertler, P. (2009). Empowering women to obtain high quality care: Evidence from an evaluation of Mexico's conditional cash transfer programme. Health Policy and Planning, 24(1), 1825. Retrieved from https://doi.org/10.1093/heapol/ czn039

Bradshaw, S. (2008). From Structural Adjustment to Social Adjustment. Global Social Policy, 8(2), 188-207. Retrieved from https://doi. org/10.1177/1468018108090638

Campos, G. (2020, May 14). Gobierno salvadoreño dio $\$ 300$ a 1.2 millones de ciudadanos: 100 mil "se desconoce cómo fueron seleccionados". La Prensa Gráfica. Retrieved from https://www.laprensagrafica. com/elsalvador/Gobierno-salvadoreno-dio-300-a1.2-millones-de-ciudadanos-100-mil-se-desconocecomo-fueron-seleccionados-20200513-0197.html

Centro de Estudios Ciudadanos. (2020, April 30). Bukele: Inmune a la pandemia del COVID19. Revista Disruptiva. Retrieved from https://www.disruptiva. media/bukele-inmune-a-la-pandemia-del-covid19/

Dirección General de Estadística y Censos. (2019). Encuesta de hogares de propósitos múltiples. Ciudad Delgado, El Salvador: Author.

Engel, E., \& Sires, A. (2020, April 29). Engel \& Sires Urge Salvadoran President to Respect Democratic Norms. [Comunicado de Prensa]. U.S. House of Representatives Committee on Foreign Affais Press Releases. Retrieved from https://foreignaffairs.house. gov/2020/4/engel-sires-urge-salvadoran-presidentto-respect-democratic-norms

Gavarrete, J. (2020a, March 23). Los \$300 para afectados por el coronavirus: las letras pequeñas de un contrato colectivo. Gatoencerrado. Retrieved from https://gatoencerrado.news/2020/03/23/los300-para-afectados-por-el-coronavirus-las-letraspequenas-de-un-contrato-colectivo/

Gavarrete, J. (2020b, April 20). Sin energía eléctrica para aplicar a un subsidio de \$300. Gatoencerrado. Retrieved from https://gatoencerrado. news/2020/04/10/sin-energia-electrica-paraaplicar-a-un-subsidio-de-300/
Gentilini, U., Almenfi, M., \& Orton, I. (2020). Social Protection and Jobs Responses to COVID-19: A RealTime Review of Country Measures. Washington, DC: World Bank. Retrieved from documents. worldbank.org/curated/en/377151587420790624/ pdf/Social-Protection-and-Jobs-Responses-toCOVID-19-A-Real-Time-Review-of-CountryMeasures-April-3-2020.pdf

González, M. (2020, May 01). Bukele contra las maras | Vivanco de Human Rights Watch: "Los atroces delitos de los pandilleros no dan carta blanca a El Salvador para vengarse de esta manera”. $B B C$ Mundo News. Retrieved from https://www.bbc.com/ mundo/noticias-america-latina-52501875.

Guzmán, V. (2020, March 30). El día en que el Gobierno falló a los más vulnerables. El Faro. Retrieved from https://elfaro.net/es/202003/el_ salvador/24207/El-día-en-que-el-Gobierno-fallóa-los-más-vulnerables.htm

Handa, S. (2009). El Dilema de la Focalización en los huérfanos en África Oriental y Meridional. Poverty in Focus, 15(1), 19-21.

Holbrook, A. L., Green, M. C., \& Krosnick, J. A. (2003). Telephone versus Face-to-Face Interviewing of National Probability Samples with Long Questionnaires. Public Opinion Quarterly, 67(1), 79125. Retrieved from https://doi.org/10.1086/346010

Lemus, E. (2020, March 22). Cuarentena obligatoria nacional de 30 días y ayudas para 1.5 millones de familias. El Faro. Retrieved from https://elfaro. net/es/202003/el_salvador/24151/Cuarentenaobligatoria-nacional-de-30-días-y-ayudas-para-15millones-de-familias.htm

McGovern, J. (2020, May 07). McGovern \& Bipartisan Group Introduce Legislation to Counter Human Rights Abuses Amidst Pandemic. Jim McGovern Congressman for the 2nd District of Massachusetts Press Releases. Retrieved from https://mcgovern.house.gov/news/documentsingle. aspx?DocumentID=398561

Molyneux, M. (2006). Mothers at the Service of the New Poverty Agenda: Progresa/Oportunidades, Mexico's Conditional Transfer Programme. Social Policy \& Administration, 40(4), 425-449.

Orellana, J. (2020a, January 07). Gobierno de El Salvador destaca ligera reducción en déficit 
fiscal. El Economista. Retrieved from https:// www.eleconomista.net/economia/Gobierno-deEl-Salvador-destaca-ligera-reduccion-en-deficitfiscal-20200107-0002.html

Orellana, J. (2020b, March 27). ICEFI propone otro mecanismo para entregar fondos a la población salvadoreña por COVID-19. El Economista. Retrieved from https://www.eleconomista.net/ economia/ICEFI-propone-otro-mecanismo-paraentregar-fondos-a-la-poblacion-salvadorena-porCOVID-19-20200327-0019.html

Paxson, C., \& Schady, N. (2007). Does Money Matter? The Effects Of Cash Transfers On Child Health And Development In Rural Ecuador. Washington, DC: World Bank. Retrieved from https://doi. org/10.1596/1813-9450-4226.

Schuering, E. (2009). Transferencias monetarias sociales en Zambia: Un proyecto en Marcha. Poverty in Focus, 15(1), 22-24.
The Economist. (2020, May 07). Nayib Bukele may want to become Latin America's first millennial dictator. The Economist. Retrieved from https:// www.economist.com/leaders/2020/05/07/nayibbukele-may-want-to-become-latin-americas-firstmillennial-dictator

Valencia, R. (2020, March 24). La 'estrategia Bukele' contra el coronavirus en El Salvador: zanahorias, palos y terror. The Washington Post. Retrieved from https://www.washingtonpost.com/es/postopinion/2020/03/24/la-estrategia-bukele-contra-elcoronavirus-zanahorias-palos-y-terror/

Vaquerano, R. (2020, April 02). La pandemia despertó al presidente de su sueño de Fepade. Factum. Retrieved from https://www.revistafactum. com/pandemia-desperto-presidente-fepade/

World Bank Gender and Development Group. (2003). Gender equality and the Millennium Development Goals. Washington, DC: World Bank.

\section{Carlos Ayala Durán}

https://orcid.org/0000-0003-4049-671X

Doctor in Rural Development by the economics faculty of the Federal University of Rio Grande do Sul (UFRGS); International researcher and consultant. E-mail: carlos.ayala@ufrgs.br 